\title{
ĐẶC ĐIỂM TỔN THƯƠNG MẮT Ở BÊ̂NH NHÂN VIÊM KHỚP DANG THẤP
}

\author{
Lê Thị Dương1, Nguyễn Văn Hùng ${ }^{1,2}$, Trần Huyền Trang1,2
}

\section{TÓM TẮT}

Mục tiêu: Mô tả đăc điểm tổn thương mắt ở bênh nhân viêm khớp dạng thấp. Đối tượng nghiên cứu: 52 bệnh nhân viêm khớp dạng thấp được chẩn đoán theo tiêu chuẩn ACR/EULAR 2010, điêuu tri nôi trú tai khoa Cơ xương khớp Bệnh viện Bạch Mai, từ tháng 10/2020 đến tháng 5/2021. Phương pháp: Nghiên cứu mô tả, cắt ngang. Kết quả: Tỉ lệ bệnh nhân có triêu chứng cơ năng ở mắt là $65,4 \%$, trong đó triêu chứng nhìn mờ là phổ biến nhất với tỉ lệ là $57,7 \%$, ngứa là $25 \%$, cảm giác khô rát là $19,2 \%$, cảm giác có vật lạ trong mắt là $15,4 \%$. Các triệu chứng đau mắt, đỏ mắt, ruối bay ít gặp hơn. Có $86,5 \%$ số bệnh nhân có tổn thương mắt phát hiện qua khám mắt. Các dạng tổn thương mắt thường găp trong nhóm bênh nhân nghiên cứu là khô mắt $(53,8 \%)$, đục thủy tinh thể $(51,9 \%)$, thoái hóa võng mạc $(15 \%)$, viêm kết mạc $(11,5 \%)$. Các tổn thương khác chiếm 19,1\%. Tỉ lệ bênh nhân có giảm thị lực là $61,5 \%$. Kết luân: Các bệnh nhân viêm khớp dạng thấp cần được khám mắt do có gần $90 \%$ có tổn thương mắt với biểu hiện đa dạng, trong đó có trên 30\% không có biểu hiện lâm sàng.

Từ khóa: Viêm khớp dạng thấp, tổn thương mắt.

\section{SUMMARY}

\section{CHARACTERISTS OF OCULAR INVOLEMENT} IN PATIENTS WITH RHEUMATOID ARTHRITIS

Objective: To describe the characteristics of ocular involement in patients with rheumatoid arthritis. Subjects: 52 patients diagnosed with rheumatoid arthritis according to ACR/EULAR 2010 criteria, treated in the Department of Rheumatology, Bach Mai hospital from October 2020 to May 2021. Methods: Crosssectional, descriptive study. Results: $65,4 \%$ of patients complained of eye symptoms, the most common sign was blurred vision $(57,7 \%)$, followed by itchy eyes $(25 \%)$, burning eyes $(19.2 \%)$, and foreign body sensation (15.4\%). Eye floaters, hot eyes, and pain in the eyes were less prevalent symptoms. Eyes examinations showed $86,5 \%$ of patients had eye involvements. Common eye problems in the patients with rheumatoid arthritis included dry eye $(53,8 \%)$, cataract $(51,9 \%)$, retinal degeneration $(15 \%)$ and conjunctivitis $(11,5 \%)$. Other abnormalitis accounted for $19,1 \%$. The proportion of patients with impaired vision was $61,5 \%$. Conclusion: Patients with rheumatoid arthritis should have their eyes examined because approximately $90 \%$ of them have ocular

${ }^{1}$ Trường Đại học Y Hà Nội

${ }^{2}$ Bênh viênn Bach Mai

Chịu trách nhiệm chính: Lê Thị Dương

Email: leduong95.hmu@gmail.com

Ngày nhận bài: 18.6.2021

Ngày phản biên khoa hoc: 16.8.2021

Ngày duyệt bài: 24.8.2021 involements with varying manifestations and more than $30 \%$ having no clinical symptoms.

Keywords: rheumatoid arthritis, ocular involement.

\section{I. ĐĂT VẤN ĐỀ}

Viêm khớp dạng thấp (VKDT) là bệnh lý viêm khớp tự miển dịch phổ biến, ảnh hưởng đênn khoảng $1 \%$ dân số thế giới [1]. Mặc dù biểu hiện tại khớp là chủ yếu nhứng các tổn thương ngoài khớp cũng rất phong phú, trong đó tổn thương mắt là khá đáng kể [2].

Tổn thương mắt gặp ở khoảng 27,2-39\% bệnh nhân VKDT với nhiều hình thái tổn thương khác nhau như khô mắt, viêm thượng củng mạc, viêm củng mạc, viêm loét giác mạc, viêm màng bồ đào, đục thủy tinh thể [3], [4]. Những tổn thương này có thể chỉ gây khó chịu nhe cho bênh nhân nhưng nếu không được phát hiện và điều trị kịp thời bệnh có thể diễn biến nặng gây mất thị lực vĩnh viễn, ảnh hưởng nặng nề đên chất lượng cuộc sống của người bệnh. Do đó, chẩn đoán sớm các tổn thương mắt ở bệnh nhân viêm khớp dạng thấp góp phần quan trọng trong việc xây dựng kế hoạch điêu trị, nhằm nâng cao chất lượng cuộc sống và giảm tî lệ tàn phế ở người bệnh. Ơ̛ Việt Nam hiên nay, các nghiên cứu về tổn thương mắt ở bềnh nhân VKDT còn hạn chế. Vì vậy, chúng tôi tiến hành nghiên cứu với mục tiêu: Mô tả đặc điểm tổn thương mắt ở bệnh nhân VKDT.

\section{II. ĐỐI TƯỢNG VÀ PHƯƠNG PHÁP NGHIÊN CỨU}

2.1 Đối tượng nghiên cứu: Nghiên cứu tiến hành trên 52 bệnh nhân được chẩn đoán xác định VKDT, điều trị nội trú tại Khoa Cơ xương khớp Bệnh viện Bạch Mai từ tháng $10 / 2020$ đến tháng $5 / 2021$.

Tiêu chuẩn lựa chọn: Bệnh nhân được chẩn đoán xác đđinh VKDT theo tiêu chuẩn ACR/EULAR 2010. Bệnh nhân đồng ý tham gia nghiên cứu.

Tiêu chuẩn loại trừ: Bênh nhân có tiền sử bỏng mắt, chấn thương mắt, có các dị tật bẩm sinh tại mắt.

\subsection{Phương pháp nghiên cứu}

- Nghiên cứu mô tả cắt ngang.

- Tất cả các bênh nhân VKDT đủ tiêu chuẩn được hỏi bệnh, khám lâm sàng và làm các xét nghiệm cần thiết.

Bệnh nhân được tiến hành khám mắt, do bác 
sĩ chuyên khoa mắt thực hiện, tại Khoa Mắt Bệnh viện Bạch Mai. Tất cả các bệnh nhân đều được khám mắt theo quy trình chuẩn và làm các thăm dò:

+ Đo thi lức

+ Đo nhãn áp

+ Soi đáy mắt đánh giá tình trạng thủy tinh thể, dịch kính, võng mạc.

+ Khám sinh hiển vi đánh giá tổn thương củng mạc, giác mạc, tiền phòng, góc tiền phòng, dịch kính, thủy tinh thể.

- Các xét nghiệm công thức máu, sinh hoá máu được làm tai Khoa Huyết hoc và Khoa Hoá sinh Bệnh viện Bạch Mai, với các giá trị tham chiếu chuẩn theo khuyến cáo.

Số liệu thu thập được thu thập theo một mẫu bệnh án nghiên cứu thống nhất.

- Xử lý số liệu: bằng phần mềm SPSS 20.0 với các thuật toán thống kê thường dùng trong y học.

III. KẾT QUẢ NGHIÊN CứU

3.1 Đặc điểm chung của nhóm bệnh nhân nghiên cứu

Bảng 1: Đặc điểm chung của nhóm bệnh nhân nghiên cứu ( $N=52)$

\begin{tabular}{|c|c|c|c|}
\hline \multicolumn{2}{|c|}{ Đặc điểm } & $\overline{\mathbf{x}} \pm \mathbf{S d}$ & $\begin{array}{c}n \\
\text { (tỉ lê \%) }\end{array}$ \\
\hline \multicolumn{2}{|c|}{ Tuối trung bình (năm) } & $57,77 \pm 11,11$ & \\
\hline \multicolumn{2}{|c|}{$\begin{array}{l}\text { Thời gian mắc bệnh } \\
\text { trung bình (năm) }\end{array}$} & $7,24 \pm 7,66$ & \\
\hline \multicolumn{2}{|c|}{ CRPhs (mg/dL) } & $3,73 \pm 4,56$ & \\
\hline \multicolumn{2}{|c|}{ DAS28-CRP } & $3,68 \pm 2,13$ & \\
\hline \multirow{2}{*}{$\begin{array}{l}\text { Giới } \\
\text { tính }\end{array}$} & Nam & & $6(11,5 \%)$ \\
\hline & Nữ & & $46(88,5 \%)$ \\
\hline \multirow{3}{*}{$\begin{array}{l}\text { Mức độ } \\
\text { hoạt } \\
\text { động } \\
\text { bệnh }\end{array}$} & Không hoạt đông & & $\frac{21(40,4 \%)}{2(3,8 \%)}$ \\
\hline & Hoạt động trung & & $13(25 \%)$ \\
\hline & Hoạt động cao & & $16(30,8 \%)$ \\
\hline \multirow[t]{2}{*}{$\mathrm{RF}$} & RF dương tính & & $48(92,3 \%)$ \\
\hline & RF âm tính & & $4(7,7 \%)$ \\
\hline
\end{tabular}

Nhận xét: Tuối trung bình là 58 tuối; chủ yếu là nữ giới $(88,5 \%)$; thời gian mắc bệnh dao động lớn (từ 6 tháng đến 35 năm); có $55,8 \%$ số bệnh nhân ở giai đoạn bệnh hoạt động và 92,3\% là RF dương tính.

Bảng 2: Phác đồ điều trị của nhóm bệnh nhân nghiên cứu ( $N=52)$

\begin{tabular}{|c|c|c|}
\hline Phác đồ & $\mathbf{n}$ & $\mathbf{\%}$ \\
\hline DMARDs kinh điến và corticoid & 10 & 19,2 \\
\hline Thuốc sinh học và Methotrexate & 8 & 15,4 \\
\hline $\begin{array}{c}\text { Thuốc sinh học, Methotrexate } \\
\text { và corticoid }\end{array}$ & 20 & 38,5 \\
\hline Chưa điêu trị cơ bản & 14 & 26,9 \\
\hline Tống & $\mathbf{5 2}$ & $\mathbf{1 0 0}$ \\
\hline
\end{tabular}

Nhận xét: Trong 52 bệnh nhân, có 14 bệnh nhân chưa được điều trị cớ bản, chiếm 26,9\%; số lượng bệnh nhân sử dụng thuốc sinh học chiếm tỉ lệ $53,9 \%$; có $19,2 \%$ bênh nhân duy trì phác đồ điều trị với DMARDs kinh điển; có 30 bệnh nhân $(57,7 \%)$ dùng corticoid.

2.3 Đặc điểm tổn thương mắt ở bệnh nhân VKDT

Bảng 3: Các triệu chứng cơ năng mắt gặp ở nhóm bệnh nhân tại thời điểm nghiên cứu

\begin{tabular}{|c|c|c|}
\hline & $\mathbf{n}$ & $\mathbf{\%}$ \\
\hline Có triệu chứng cơ năng ở mắt & 34 & 65,4 \\
\hline Cảm giác có vật lạ trong mắt & 8 & 15,4 \\
\hline Khố rát & 10 & 19,2 \\
\hline Đau mắt & 3 & 5,8 \\
\hline Đỏ mắt & 5 & 9,6 \\
\hline Ngứa & 13 & 25 \\
\hline Tăng xuất tiết & 7 & 13,5 \\
\hline Nhìn mờ & 30 & 57,7 \\
\hline Ruối bay & 3 & 5,8 \\
\hline Tiền sứ có bệnh mắt & 5 & 9,61 \\
\hline
\end{tabular}

Ghi chú: một bệnh nhân có thể đồng thời có nhiều triệu chứng.

Nhận xét: Có $65,4 \%$ bệnh nhân có triệu chứng cơ năng tại mắt. Trong đó, triệu chứng nhìn mờ là phổ biến nhất với tỉ lệ là $57,7 \%$, tiếp theo là các biểu hiện ngứa mắt $(25 \%)$, khô rát $(19,2 \%)$, cảm giác có vật lạ trong mắt $(15,4 \%)$.

Bảng 4: Các tổn thương thực thể ở măt trong nhóm bệnh nhân tại thời điểm nghiên cứu

\begin{tabular}{|c|c|c|}
\hline & $\mathbf{n}$ & $\mathbf{\%}$ \\
\hline Có tốn thương mắt & 45 & 86,5 \\
\hline Giảm thị lực & 32 & 61,5 \\
\hline Glocom góc đóng & 1 & 1,9 \\
\hline Viêm kết mạc & 6 & 11,5 \\
\hline Viêm loét giác mạc & 1 & 1,9 \\
\hline Đục thủy tinh thế & 27 & 51,9 \\
\hline Đục dịch kính & 3 & 5,8 \\
\hline Thoái hóa võng mạc & 15 & 28,8 \\
\hline Màng xơ võng mạc & 2 & 3,8 \\
\hline Lô hoàng điếm & 1 & 1,9 \\
\hline Khô mắt & 28 & 53,8 \\
\hline Mộng mắt & 1 & 1,9 \\
\hline Xuất tiết võng mạc & 1 & 1,9 \\
\hline Ghín chụ̂t bện nhân có thế đông thơ có
\end{tabular}

Ghi chú: một bệnh nhân có thể đồng thời có nhiều tổn thương.

Nhận xét: Gần $90 \%$ bệnh nhân có tổn thương thực thể tại mắt ở thời điểm nghiên cứu, tỉ lệ bệnh nhân có giảm thị lực là $61,5 \%$. Một số dạng tổn thương mắt thường gặp là khô mắt $(53,8 \%)$, đục thủy tinh thể $(51,9 \%)$, thoái hóa võng mạc (15\%), viêm kết mạc $(11,5 \%)$. 


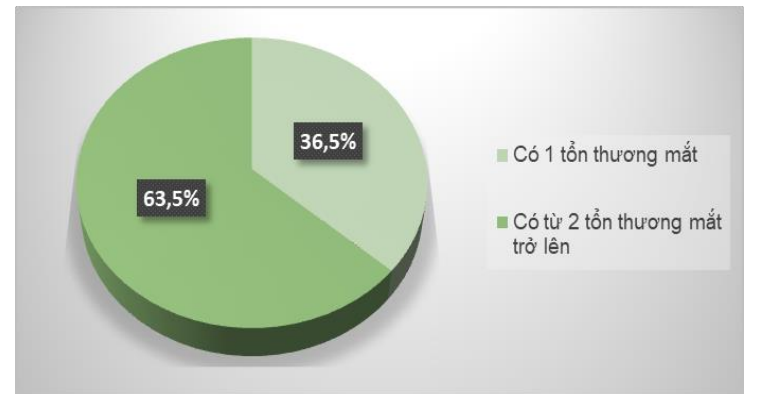

Biểu đồ 1: Phân bố bênh nhân theo số Iương tổn thương tai mắt

Nhận xét: Đa số bệnh nhân có từ 2 tổn thương mắt trở lên, chiếm tỉ lệ là 63,5\%.

\section{BÀN LUÂN}

4.1 Đăc điểm chung của nhóm đối tượng nghiên cứu. Nghiên cứu của chúng tôi trên 52 bệnh nhân VKDT có độ tuổi trung bình là $57,77 \pm 11,11$ tuổi và chủ yếu là nữ giới, chiếm tỉ lệ $88,5 \%$, phù hợp với các kết quả nghiên cứu trước đây cho thấy VKDT thường gặp ở nữ giới, độ tuổi trung niên.

Thời gian mắc bệnh trung bình là 7,24 $\pm 7,66$ năm, trong đó bệnh nhân có thời gian mắc bệnh ngắn nhất là 6 tháng, dài nhất là 35 năm. Tại thời điểm nghiên cứu, đánh giá theo thang điểm DAS28-CRP, 23 bệnh nhân (44,2\%) ở giai đoạn lui bệnh và hoạt động bệnh thấp, 29 bệnh nhẩn $(55,8 \%)$ có mức độ hoạt động bệnh trung bình và cao, với nồng độ CRPhs trung bình của nhóm đối tượng nghiên cứu là $3,73 \pm 4,56 \mathrm{mg} / \mathrm{dL}$. Phần lớn các bênh nhân dương tính với yếu tố dạng thấp RF (92,3\%). Các kết quả này phù hợp với đặc điểm của bệnh viêm khớp dạng thấp là môt bệnh diễn biến mạn tính với các đợt tiến triển, sự xuất hiện của yếu tố dạng thấp và các chỉ số viêm thường tăng cao vào các giai đoạn hoạt động của bênh.

4.2 Đắc điểm tổn thương mắt ở bênh nhân VKDT. Viêm khớp dang thấp là bênh viêm khớp tự miễn dịch phổ biến, với biểu hiện chủ yếu tại các khớp nhưng có nhiều trường hợp có các tổn thương ngoài khớp nặng và nghiêm trong, trong đó có biểu hiện tai mắt. Tỉ lệ tổn thương mắt ở bệnh nhân VKDT được báo cáo thay đổi trong các nghiên cứu. Theo nghiên cứu của Eldaly và cộng sự trên 70 bệnh nhân VKDT, các tổn thương mắt được phát hiên ở $70 \%$ số bệnh nhân [5]. Tuy nhiên, trong các nghiên cứu trước đó, tî lệ này được báo cáo chỉ vào khoảng 27,2-39\% [3], [4].

Trong nghiên cứu của chúng tôi, $65,4 \%$ bênh nhân báo cáo có các biểu hiện ở mắt cho thây đây là một trong các nhóm triẹu chứng khá thường gặp ở các bệnh nhân viêm khớp dạng thấp. Bất thường phổ biến nhất là tình trạng nhìn mờ, chiếm $57,7 \%$, sau đó là các triệu chứng như ngứa mắt, cảm giác khô rát ở mắt, có vật lạ trong mắt. Các triệu chứng đau mắt, đỏ mắt, ruồi bay ít gặp hơn. Tuy nhiên, đánh giá thị lực bằng máy cho thây $32 / 52$ bệnh nhân, chiếm $61,5 \%$ có giảm thị lực thực sự, cao hơn số lượng bệnh nhân có biểu hiện nhìn mờ. Giảm thị lực có thể là biểu hiện mới xuất hiện nhưng có thể là tổn thương xuất hiện sớm trong quá trình tiến triển của bênh VKDT và người bênh có thể thích nghi với tình trạng giảm thị lực kéo dài do đó ít được người bệnh để ý và đi khám ở giai đoạn sớm. Việc thăm khám mắt nếu không được đưa vào quy trình khám bệnh thường quy có thể khiến người bệnh được phát hiện tổn thương ở giai đoạn muộn, gây khó khăn cho quá trình điều trị và phục hồi tổn thương.

Tại thời điểm được lựa chọn vào nghiên cứu, có 45/52 bệnh nhân có vấn đề về mắt, được phát hiện qua khám chuyên khoa mắt, chiếm $86,5 \%$. Trong nghiên cứu của chúng tôi, các tổn thương về mắt được phát hiện lần đâu ở phần lớn các trường hợp. Chỉ có $5 / 52(9,61 \%)$ bệnh nhân đã được chẩn đoán và điều trị bệnh mắt trước đó. Điểu này cho thấy các tổn thương mắt chưa thực sự được chú trọng trong quá trình khám, theo dõi và điều trị bệnh VKDT. Các biểu hiện bệnh lý ở mắt có thể liên quan tới nhiều yếu tố như tuổi, tiền sử bệnh mắt, tiền sử dùng thuốc, và là triệu chứng của bệnh VKDT. VKDT là một bệnh tự miễn, có ảnh hưởng lên nhiều cơ quan trong cơ thể [2]. Theo một số tác giả, các thành phần nhãn câu có chứa proteoglycans và collagen, giống như cấu trúc của khớp. Sự tương tự về cấu trúc mô học này có thể là nguyển nhân dẫn đến các biểu hiển tại mắt ở bệnh nhân VKDT [6]. Thêm vào đó, một số thuốc điều trị VKDT như Hydroxychloroquine (HCQ) có thể lắng đọng ở võng mạc gây tổn thương võng mạc, làm giảm thị lực. Việc sử dụng glucocorticoid liều cao, kéo dài cũng làm tăng nguy cơ đục thủy tinh thể và tăng nhãn áp [7]. Trong nghiên cứu của chúng tôi, $57,7 \%$ bênh nhân vần cần corticoid để kiểm soát triệu chứng bệnh, 55,8\% bệnh nhân đang ở mức độ hoạt động trung bình và mạnh tại thời điểm nghiên cứu.

Các dạng bệnh lý mắt thường gặp nhất ở các bênh nhẩn trong nghiên cứu của chúng tôi bao gồm khô mắt, đục thủy tinh thể, thoái hóa võng mạc, viêm kết mạc (tî lệ tương ứng là 53,8\%, $51,9 \%, 15 \%$ và $11,5 \%)$. Đa số bệnh nhân 
(33/52, chiếm 63,5\%) có từ 2 tổn thương mắt trở lên. Tất cả các tổn thương bệnh lý ở trên có thể là các yếu tố chủ yếu dẫn đến tình trạng giảm thị lực gặp ở đa số bệnh nhân VKDT (chiếm 61,5\%) trong nghiên cứu. Kết quả này tương tự với nghiên cứu của Nguyễn Vính Ngọc và cộng sự trên 160 bênh nhân VKDT, trong đó có 100 bệnh nhân VKDT đơn thuần và 60 bệnh nhân VKDT có hội chứng Sjogren [8]. Các nghiên cứu trên thế giới cũng cho thấy tổn thương mắt liên quan đến bệnh VKDT bao gồm khô mắt, viêm thượng củng mạc, viêm củng mạc, viêm màng bồ đào, tổn thương giác mạc, võng mạc..., trong đó khô mắt là biểu hiện thường gặp nhất nhưng cũng dễ bị bỏ sót nhất. Khô mắt nểu không được điều trị có thể dẫn tới viêm loét thậm chí nhuyển giác mạc [6]. Các bệnh lý mắt khác gặp với tỉ lệ không cao nhưng nó có thể là gợi ý để bác sî́ tầm soát các bênh lý toàn thân hoắc có thể coi là một yếu tố tiên lượng của bệnh VKDT cùng với các biểu hiện ngoài khớp khác [2].

\section{KẾT LUÂN}

Gần $90 \%$ bệnh nhân có tổn thương mắt phát hiện qua khám mắt, trong đó có trên $30 \%$ bệnh nhân không có biểu hiện lâm sàng. Các tổn thương mắt khá đa dạng, thường gặp nhất là khô mắt, đục thủy tinh thể.

\section{TÀI LIÊU THAM KHẢO}

1. Widdifield J, Paterson JM, Bernatsky S và cộng sự. The epidemiology of rheumatoid arthritis in Ontario, Canada. Arthritis Rheumatol Hoboken $\mathrm{NJ}, 2014,66(4)$ : p786-793.

2. Prete M., Racanelli V., Digiglio L. và công sự. Extra-articular manifestations of rheumatoid arthritis: An update. Autoimmun Rev, 2011, 11(2): p123-131.

3. Zlatanović G, Veselinović D, Cekić S, Živković M, Đorđević-Jocić J, Zlatanović M. Ocular manifestation of rheumatoid arthritis-different forms and frequency. Bosn J Basic Med Sci, 2010, 10(4): p323-327.

4. Vignesh APP, Srinivasan R. Ocular manifestations of rheumatoid arthritis and their correlation with anticyclic citrullinated peptide antibodies. Clinical Ophthalmology, 2015, 9: p393-397.

5. Eldaly ZH, Saad SA, Hammam N. Ocular surface involvement in patients with rheumatoid arthritis: Relation with disease activity and duration. Egypt Rheumatol, 2020, 42(1): p5-9.

6. Artifoni M., Rothschild P.-R., Brézin A. và cộng sự. Ocular inflammatory diseases associated with rheumatoid arthritis. Nat Rev Rheumatol, 2014, 10(2): p108-116.

7. Fel A., Aslangul E., và Le Jeunne C. Indications et complications des corticoïdes en ophtalmologie. Presse Médicale, 2012, 41(4): p414-421.

8. Nguyễn Vĩnh Ngọc. Nghiên cứu hôi chứng Gouregot- Sjogren trong bệnh viêm khớp dạng thấp và luput ban đỏ hể thổng, Luận án tiến sĩ y học, Trường Đại học Y Hà Nội, 2004.

\section{ĐÁNH GIÁ NGUY CƠ TIM MACH TRÊN BỆNH NHÂN VẢY NẾN TẠI BỆNH VIỆN DA LIỄU TRUNG ƯO'NG}

\section{TÓM TẮT.}

Mục tiêu: Đánh giá nguy cơ tim mạch trên bệnh nhân vảy nến thông qua thực trạng các yếu tố nguy cơ và ước lượng nguy cơ tim mạch trong 10 năm bằng thang điểm Framingham. Đối tượng và phương pháp: Nghiên cứu mô tả cắt ngang trên nhóm nghiên cứu gồm 306 bệnh nhân vảy nến và nhóm đối chứng gồm 306 bệnh nhân được chẩn đoán bệnh da thông thường, thời gian từ tháng 8/2020 đến tháng 8/2021. Cả 2 nhóm đượcmô thả thực trạng các yếu tố nguy cơ tim mạch như: hút thuốc lá, uống rượu bia, stress, thiếu hoạt động thể lực, thừa cân - béo phì, tăng huyết áp, đái tháo đường, rối loạn lipid máu. Sau đó

\footnotetext{
${ }^{1}$ Trường đại học Y Hà Nội

²Bệnh viện Da liễu Trung ương

Chịu trách nhiệm chính: Đỗ Thu Thảo

Email: bsthao2591@gmail.com

Ngày nhận bài: 22.6.2021

Ngày phản biện khoa học: 20.8.2021

Ngày duyệt bài: 27.8.2021
}

\section{Đỗ Thu Thảo1, Phạm Thị Lan ${ }^{1,2}$}

tính nguy cơ tim mạch dựa trên các yếu tố là tuổi, giới, tình trạng hút thuốc lá, đái tháo đường, HATT $(\mathrm{mmHg})$, nông độ Cholesterol TP và $\mathrm{HDL}-\mathrm{C}(\mathrm{mmol} / \mathrm{L})$. Điểmnguy cơ tim mạch được tính dựa trên chương trình Framingham Heartwebsite: https://framinghamheartstudy.org/fhs-risk-

functions/cardiovascular-disease-10-year-risk. Kết quả: Bệnh nhân vảy nến có các yếu tố nguy cơ tim mạch cao hơn cóý nghĩa so với nhóm đối chứng là hút thuốc lá $(26,1 \%$ so với $19 \% ; p=0,033)$, stress $(46,1 \%$ so với $19 \%$; $p<0,01)$, thừa cân - béo phì $(38,6 \%$ so với $28,4 \% ; p=0,008)$, tăng huyêtáp $(32,4 \%$ so với $11,8 \%$; $p<0,01)$, đái tháo đường $(17,3 \%$ so với $7,5 \% ; p<0,01)$, rối loạn lipid máu (55,9\% so với $35,3 \% ; p<0,01)$. Tình trạng uống rượu bia và thiếu hoạt động thể lực khác biệt không có ý nghĩa thống kê (kết quả lần lượt là $36,6 \%$ so với $32,4 \% ; p=0,269$ và $58,2 \%$ so với $56,2 \% ; p=$ $0,624)$. Nguy cơ tim mạch trong 10 năm tớiở nhóm vảy nến cao hơn nhómđối chứng $(12,7 \pm 9,5 \%$ so vớ $9,1 \pm 6,9 \% ; p<0,01)$. Nhóm vảy nến có tỷ lệ bệnh nhân nguy cơ cao nhiều hơn nhóm đối chứng (23,9\% so với 13,1\%; $p<0,01)$. Đặc biệt, thông qua mô hình 